\title{
Nota
}

\section{MODELLING OF SOIL PENETRATION RESISTANCE FOR AN OXISOL UNDER NO-TILLAGE ${ }^{(1)}$}

\author{
João Tavares Filho(2), Clarissa Tieme Matsuda Feltran(3), José \\ Francirlei de Oliveira $^{(3)} \&$ Edinei de Almeida ${ }^{(3)}$
}

\begin{abstract}
SUMMARY
Soil penetration resistance is an important property that affects root growth and elongation and water movement in the soil. Since no-till systems tend to increase organic matter in the soil, the purpose of this study was to evaluate the efficiency with which soil penetration resistance is estimated using a proposed model based on moisture content, density and organic matter content in an Oxisol containing 665,221 and $114 \mathrm{~g} \mathrm{~kg}^{-1}$ of clay, silt and sand respectively under annual no-till cropping, located in Londrina, Paraná State, Brazil. Penetration resistance was evaluated at random locations continually from May 2008 to February 2011, using an impact penetrometer to obtain a total of 960 replications. For the measurements, soil was sampled at depths of 0 to $20 \mathrm{~cm}$ to determine gravimetric moisture (G), bulk density (D) and organic matter content $(M)$. The penetration resistance curve $(P R)$ was adjusted using two non-linear models $\left(\mathrm{PR}=a \mathrm{D}^{b} \mathrm{G}^{c}\right.$ and $\left.\mathrm{PR}^{\prime}=a \mathrm{D}^{b} \mathrm{G}^{c} \mathrm{M}^{\mathrm{d}}\right)$, where $\mathrm{a}, \mathrm{b}, \mathrm{c}$ and $\mathrm{d}$ are coefficients of the adjusted model. It was found that the model that included $M$ was the most efficient for estimating PR, explaining $91 \%$ of PR variability, compared to $82 \%$ of the other model.
\end{abstract}

Index terms: no-till, compaction, physical properties, organic matter.

(1) Received for publication in May 3, 2011 and approved in November 11, 2011.

(2) Associate Professor, Londrina State University, CCA/AGR, C.P. 6001, CEP 86051-990 Londrina (PR). Email: tavares@uel.br

(3) Agronomics Post-Graduate students, Londrina State University, CAPES Scholarships. E-mails: clarissatieme@hotmail.com; jfoliveira79@yahoo.com; edineialm@gmail.com 


\title{
RESUMO: MODELAGEM DA RESISTÊNCIA DO SOLO À PENETRAÇÃO PARA UM LATOSSOLO SOB SISTEMA DE SEMEADURA DIRETA
}

\begin{abstract}
A resistência mecânica do solo é um importante atributo que altera o crescimento e alongamento das raizes e o movimento da água no solo. Considerando que a semeadura direta tende a aumentar o teor de matéria orgânica do solo, o objetivo deste trabalho foi analisar o ajuste da curva de resistência do solo à penetração considerando a umidade, a densidade e o teor de argila e de matéria orgânica, em um Latossolo Vermelho eutroférrico com 665, 221 e $114 \mathrm{~g} \mathrm{~kg}^{-1}$ de argila, silte e areia, respectivamente, sob culturas anuais em plantio direto, localizado em Londrina, Paraná. A resistência à penetração foi avaliada de forma aleatória e de maneira ininterrupta entre os meses de maio de 2008 e fevereiro de 2011, mediante o uso do penetrômetro de impacto, num total de 960 repetições. No momento da determinação, foram coletadas amostras entre 0 e $20 \mathrm{~cm}$ de profundidade, para determinação da umidade gravimétrica $(G)$, da densidade do solo $(D)$ e do teor de matéria orgânica (M). A curva de resistência do solo à penetração (RP) do solo foi ajustada por dois modelos não lineares $\left(R P=a D^{b} G^{c}\right.$ e $\left.R P^{\prime}=a D^{b} G^{c} M^{d}\right)$, em que $a, b, c$ e d são coeficientes de ajuste do modelo. O modelo com inclusão da $M$ apresentou coeficiente de determinação de $91 \%$, ao passo que o modelo sem inclusão desta variável apresentou coeficiente de determinação de $82 \%$.
\end{abstract}

Termos de indexação: plantio direto, compactação, atributos físicos, matéria orgânica.

\section{INTRODUCTION}

Soil mechanical resistance is an important property that affects root growth and elongation and water movement in the soil. Most commonly, this property is evaluated using an impact penetrometer which works on the principle of soil penetration resistance $(\mathrm{PR})$ with a vertical impact representing a force $(\mathrm{F})$ on a rigid rod that drives a cone of specific size into the soil (Vaz \& Hopmans, 2001).

The importance of determining $\mathrm{PR}$ is the correlation with the effect of heavy machinery passing over the soil, affecting root growth and the soil physical properties, and is a way of rapidly obtaining results. However, PR is influenced by a number of soil properties such as density, moisture content, water potential, texture, aggregation, cementation, organic matter content and mineralogy, which has led some authors to propose empirical models to describe PR (Busscher, 1990; Busscher et al., 1997; Ribon \& Tavares Filho, 2004; To \& Kay, 2005; Dexter et al., 2007; Lima et al., 2007; Ribon \& Tavares Filho, 2008; Almeida et al., 2008). Soil moisture content and bulk density are considered the most significant of these properties (Silva \& Kay, 1997; Imhoff et al., 2000), and the model most commonly used to estimate PR is that proposed by Busscher (1990), in which PR is obtained as a function of bulk density and moisture content $(\theta)$, and regression parameters "a", 'b" and "c" are obtained by non-linear adjustments that vary from one soil to another.
According to Dexter et al. (2007), this model can work very well for any type of soil, but when considering a set of soils, additional pedotransfer functions (PTF) are often used, and the coefficients "a", "b", "c" determined by experimentation and regression. Thus, to validate the data obtained with a penetrometer, provided it is used correctly, the soil must have been characterized (Oliveira et al., 2007), which is not always the case.

No-till systems that produce grain for the domestic and export markets is widespread in southern Brazil. This farming system tends to cause minor structural changes, since the soil is not plowed. However, according to Collares et al. (2006), the absence of plowing combined with more intensive land use exposes the soil, often under inappropriate moisture content conditions, to heavy machinery traffic, contributing to variations in bulk density and changing the soil structure, affecting penetration resistance, water storage and nutrient availability to plants. In addition, no-till farming tends to increase the organic matter in the soil, which probably increases the soil elasticity (Soane, 1990), more than mineral particles. It also promotes the formation and stabilization of soil aggregates (Carpenedo \& Mielnizuk, 1990), acting on the soil structure and possibly helping increase the soil mechanical resistance to compaction, as reported by Silva et al. (2000).

Thus, quantifying the soil moisture content, density and organic matter content is fundamental for penetrometer measurements, aside from 
identifying the soil class and clay content. Ribon \& Tavares Filho (2008) tried to estimate the PR of a very clayey eutroferric Red Oxisol (Latossolo Vermelho), under different soil moisture content conditions, in addition to considering density, clay content and organic matter content. The results showed that, when the soil is drier, the most influential properties for PR estimates are density and organic matter content. At higher soil moisture, the most influential properties on PR estimates are density and moisture content. The soil clay content did not explain the variation in soil values, probably due to the low variability in the clay content of the soil under investigation.

Thus, the purpose of this study was to examine adjustments in the soil penetration resistance curve of a eutroferric Red Oxisol (Latossolo Vermelho) under annual no-till cropping, based on the determination coefficient, mean absolute relative errors and the correlation coefficient, taking account of moisture content, density, clay content and organic matter content.

\section{MATERIALS AND METHODS}

The data in this study were collected from a eutroferric Red Oxisol (Brazilian classification: LVef). The soil physical, chemical and mineralogical characteristics are given in table 1 . The land is used for annual soybean, maize, wheat and oats in the no-till system (annual no-till cropping: ANTC). Its location is latitude $23^{\circ} 08^{\prime} 47^{\prime \prime}-23^{\circ} 55^{\prime} 46^{\prime \prime} \mathrm{S}$, longitude $50^{\circ} 52^{\prime} 23^{\prime \prime}-51^{\circ} 19^{\prime} 11^{\prime \prime} \mathrm{W}$, at $610 \mathrm{~m}$ asl. The local climate was classified as Cfa (humid subtropical) according to Köppen, with rainfall in all seasons (annual rainfall of around $1260 \mathrm{~mm}$ ).
Penetration resistance (PR) was evaluated randomly and continually between May 2008 and February 2011 using an impact penetrometer (IAA/Planalsucar, impact weight $4 \mathrm{~kg}$, free fall $40 \mathrm{~cm}$ ) (Stolf et al., 1983), with a total of 960 replications. The impact results in $\mathrm{dm}^{-1}$ were converted into $\mathrm{MPa}$, expressing resistance to cone penetration of the soil in pressure units, using the following formula (Stolf, 1991): $\mathrm{PR}\left(\mathrm{kgf} \mathrm{cm}^{-2}\right)=$ $5.6+6.89 \mathrm{~N}\left(\right.$ impacts $\left.\mathrm{dm}^{-1}\right)$. To convert $\mathrm{PR}$ into $\mathrm{kgf}^{-2} \mathrm{~cm}^{-2}$ for Mpa, the result is multiplied by a constant, 0.0981 . For determining the $\mathrm{PR}$, samples $(\mathrm{N}=960)$ we collected at depths of between 0 and $20 \mathrm{~cm}$ to determine the gravimetric moisture content $(\mathrm{G})$ and organic matter content (M) of the soil using the methods proposed by Embrapa (1997), and bulk density (D) by the volumetric ring $\left(98 \mathrm{~cm}^{3}\right)$ method, in undisturbed samples. Because PR was determined over a lengthy period, there was wide variation in $\mathrm{G}$, and values for $\mathrm{D}$ and organic matter content also varied.

\section{Procedure to test the effect of including $M$ content in the model}

Multiple regression was used, in which the dependent variable was PR and the independent variables the variation in values of $G, D$ and $M$ throughout the sampling period ( $\mathrm{N}=960$ samples). The penetration resistance curve was obtained using two non-linear models, i.e. the control model proposed by Busscher (1990) and a second model based on the first, but including organic matter content: $P R=a D^{b} G^{c}$ and $P R '=a D^{b} G^{c} M^{d}$, where $\mathrm{PR}=$ soil penetration resistance $(\mathrm{MPa}), \mathrm{D}=$ bulk density $\left(\mathrm{Mg} \mathrm{m}^{-3}\right), \mathrm{G}=$ gravimetric moisture content ( $\mathrm{kg} \mathrm{kg}^{-1}$ ) obtained from samples collected in the field during the PR tests, $\mathrm{M}=$ organic matter content in the soil $\left(\mathrm{g} \mathrm{kg}^{-1}\right)$, and "a", "b", "c" and "d" = model adjustment coefficients.

Table 1. Physical and chemical characterization(1) of samples of eutroferric Red Oxisol (LVef) under annual no-till cropping (ANTC)

\begin{tabular}{|c|c|}
\hline Sample collection depth & $0-0.2 \mathrm{~m}$ \\
\hline Clay $\left(\mathrm{g} \mathrm{kg}^{-1}\right)^{(2)}$ & 665 \\
\hline Silt $\left(\mathrm{g} \mathrm{kg}^{-1}\right)^{(2)}$ & 221 \\
\hline Sand $\left(\mathrm{g} \mathrm{kg}^{-1}\right)^{(2)}$ & 114 \\
\hline Particle density $\left(\mathrm{kg} \mathrm{dm}^{-3}\right)^{(2)}$ & 2.91 \\
\hline $\mathrm{M}\left(\mathrm{g} \mathrm{kg}^{-1}\right)^{(2)}$ & 25.60 \\
\hline $\mathrm{pH}\left(\mathrm{H}_{2} \mathrm{O}\right)^{(2)}$ & 5.70 \\
\hline CEC pH7.0 $\left(\mathrm{cmol}_{\mathrm{c}} \mathrm{dm}^{-3}\right)^{(2)}$ & 9.70 \\
\hline $\mathrm{V}(\%)^{(2)}$ & 54.00 \\
\hline $\mathrm{Al}\left(\mathrm{cmol}_{\mathrm{c}} \mathrm{dm}^{-3}\right)^{(2)}$ & 0.20 \\
\hline Specific surface area $\left(\mathrm{m}^{2} \mathrm{~g}^{-1}\right)^{(3)}$ & 6.01 \\
\hline Mineralogy ${ }^{(4)}$ & $\begin{array}{c}\text { Trace minerals } 2: 1 \text {, kaolinite, } \\
\text { iron oxide }\left(\mathrm{Fe}_{2} \mathrm{O}_{3}\right) \text {, gibbsite }\left(\mathrm{Al}(\mathrm{OH})_{3}\right)\end{array}$ \\
\hline
\end{tabular}

(1) The results are averaged across 20 soil sampled randomly from the eutroferric Red Oxisol (LVef) soil area under ANTC, before impact penetrometer measurements. (2)Analyses conducted by Embrapa (1997). (3)Analysis conducted using the EGME method (ethylene glycol monomethyl ether). ${ }^{(4)} \mathrm{X}$ ray diffraction analysis. 
These models were linearized by applying logarithmic functions: $\ln P R=\ln a+b \ln D+c \ln G$ and $\ln P R=\ln a+b \ln D+c \ln G+d \ln M$ and the soil resistance curves adjusted using the PROC REG procedure (SAS, 1991). After adjusting the data obtained, the estimated coefficients were used to transform the linearized into non-linear models. To test the regression significance level (confirming the hypothesis that the averages of the variables are statistically equal), we used a significance level (F) of $5 \%$. In addition, the $\mathrm{R}^{2}$ values of the two equations were compared to check the adjustment to the PR data as a function of the variables $D, G$ and $\mathrm{M}$ and also to test if adding a new independent variable, in this case $M$ (model 2 ), would cause a reduction instead of increasing the $R^{2}$ value, to justify including this variable in the model.

The models and associated coefficients were used to calculate estimated and absolute values of PR, verify the correlation between the results and evaluate the deviations between the estimates based on the models and the experimental data. For this purpose, the mean absolute relative error (ع) was determined as described by Khoury Júnior et al. (2004): $\varepsilon=\frac{100}{n} \sum_{i=1}^{n}\left(\frac{\left|Y-Y_{0}\right|}{Y}\right)$, where $\mathrm{Y}$ is the observed experimental value, $\mathrm{Y}_{0}$ the value calculated using the models, and $\mathrm{n}$ the number of experimental observations. The simulation was considered good (adjustments close to the experimental data) when $\varepsilon<10$ and bad (adjustments further away from the experimental data) when $\varepsilon \leq 10$ (Mohapatra \& Rao, 2005). Finally, the model that best matched the experimental data was subjected to analysis of variance and the averages compared by a $5 \%$ Tukey test.

\section{RESULTS AND DISCUSSION}

Statistical moments of the variables of the layer 0-20 cm in eutroferric Red Oxisol under no-till cropping (Table 2 ) show a high CV (> $20 \%$ ) for PR and $\mathrm{M}$ due to the large amplitude of the values of these two properties, and a medium $\mathrm{CV}$ for $\mathrm{G}$ and $\mathrm{D}(\leq 20 \%)$ due to their lower amplitude, indicating that the data collected in the field were accurate. According to Cargnelutti Filho \& Storck (2007), researchers seem to come to a consensus to use the $\mathrm{CV}$ as a measure of experimental accuracy, where medium, high or very high CVs indicate satisfactory experimental accuracy. The results are in line with Ribon \& Tavares Filho (2008), who also observed a high CV for PR and $\mathrm{M}$ and a medium CV for $\mathrm{G}$ and $\mathrm{D}$ when working on Red Oxisol under annual crops.

Adjustments to the PR data models as a function of $\mathrm{G}, \mathrm{D}$ and $\mathrm{M}$ are given in table 3. Note that model 1, with the PR data adjusted as a function of $\mathrm{D}$ and $\mathrm{G}$, explains $82 \%\left(\mathrm{R}^{2}=0.82\right)$ of the variability of PR, whereas model 2 , with PR adjusted as a function of $\mathrm{D}, \mathrm{G}$ and $\mathrm{M}$, explains $91 \%\left(\mathrm{R}^{2}=0.91\right)$ of the variability of PR. Therefore, model 2 fit better to the PR curve than model 1 , based on the resulting $R^{2}$, mainly because $M$ is normally a variable soil property. These results are in line with Fidalski \& Tormena (2007), Lima et al. (2007); Almeida et al. (2008); Blainski et al. (2008), who all worked on different soils (dystrophic oxisolic Red Acrisol, sandy dystrophic Red Acrisol, sandy textured Red-Yellow Oxisol, Quartzarenite Arenosol, Red-Yellow Acrisol, dystrophic Red Oxisol and acriferric Red Oxisol) and used different methods of PR determination (in the field and laboratory), but obtained a coefficient of determination between 0.71 and 0.87 .

The coefficients of the two models (Table 3) were significant by the t-test $(p \leq 0.05)$ and the signs indicate that $P R$ varied positively with $D$ and negatively with G, in line with Imhoff et al. (2000), Araújo et al. (2004), Silva et al. (2004), Ribon \& Tavares Filho (2008) and Blainski et al. (2008). For $\mathrm{M}$, the variation in PR was also negative. The highest absolute values for coefficients " $a$ ", " $b$ " and " $c$ " for model 1 (Table 3) indicate that the PR estimates (Figure 1) adjusted in this model were higher than with the adjustments allowed in model 2 (Table 3), including the variable $\mathrm{M}$.

Table 2. Descriptive statistics for the variables analyzed at depths of 0-20 cm in eutroferric Red Oxisol under annual no-till cropping

\begin{tabular}{|c|c|c|c|c|c|c|c|}
\hline \multirow{2}{*}{ Variable } & \multicolumn{7}{|c|}{ Descriptive statistic } \\
\hline & $\mathbf{N}$ & Average & Dev. & Mode & Min. & Max. & CV (\%) \\
\hline $\mathrm{PR}(\mathrm{MPa})$ & \multirow{4}{*}{960} & 3.29 & 1.54 & 2.00 & 1.80 & 7.66 & 46.81 \\
\hline $\mathrm{G}\left(\mathrm{kg} \mathrm{kg}^{-1}\right)$ & & 0.25 & 0.05 & 0.24 & 0.13 & 0.43 & 20.00 \\
\hline $\mathrm{D}\left(\mathrm{Mg} \mathrm{dm}^{-3}\right)$ & & 1.46 & 0.15 & 1.44 & 1.20 & 1.67 & 10.27 \\
\hline $\mathrm{M}\left(\mathrm{g} \mathrm{kg}^{-1}\right)$ & & 32.50 & 7.76 & 34.50 & 12.01 & 40.00 & 23.59 \\
\hline
\end{tabular}

PR: soil mechanical penetration resistance; G: gravimetric moisture content; D: bulk density; M: organic matter; N: number of samples. 
Table 3. Linear regression coefficient estimated for soil penetration resistance curves $(\ln P R=\ln a+b \ln D$ $\left.+c \ln G ; \ln P R^{\prime}=\ln a+b \ln D+c \ln G+d \ln M\right)$ for a eutroferric Red Oxisol under annual no-till cropping

\begin{tabular}{|c|c|c|c|c|}
\hline Coefficient & Estimate & Standard error & $\mathbf{t}$ & P-value \\
\hline \multicolumn{5}{|c|}{ Model 1: $\mathrm{PR}=0.1239 \mathrm{D}^{3.4119} \mathrm{G}^{-1.3701}\left(\mathrm{R}^{2}=0.82 ; \mathrm{F}>\mathrm{F}_{\text {sig. }}\right)$} \\
\hline$a$ & -2.0883 & 0.0676 & -30.88 & 0.0000 \\
\hline$b$ & 3.4119 & 0.0370 & -37.04 & 0.0000 \\
\hline$c$ & -1.3701 & 0.1176 & 29.02 & 0.0000 \\
\hline \multicolumn{5}{|c|}{ Model 2: $\mathrm{PR} \mathrm{R}^{\prime}=1.6307 \mathrm{D}^{2.5663} \mathrm{G}^{-1.0692} \mathrm{M}^{-0.5321}\left(\mathrm{R}^{2}=0.91 ; \mathrm{F}>\mathrm{F}_{\text {sig. }}\right)$} \\
\hline$a$ & 0.4890 & 0.1248 & 3.92 & 0.0001 \\
\hline$b$ & 2.5663 & 0.1014 & 22.31 & 0.0000 \\
\hline$c$ & -1.0692 & 0.0325 & -32.92 & 0.0000 \\
\hline$d$ & -0.5321 & 0.0232 & -25.94 & 0.0000 \\
\hline
\end{tabular}

PR: soil penetration resistance (MPa); D: bulk density $\left(\mathrm{Mg} \mathrm{m}^{-3}\right)$; G: soil gravimetric moisture content $\left(\mathrm{kg} \mathrm{kg}^{-1}\right)$ and $\mathrm{M}$ : soil organic matter $\left(\mathrm{g} \mathrm{kg}^{-1}\right)$.

The influence of $\mathrm{M}$ on $\mathrm{PR}$ was also evident in studies conducted by Carter (1990) and Ribon \& Tavares Filho (2004) and this effect is probably due to the fact that $M$ affects soil aggregation and structure (Sá \& Santos Junior, 2005), and also reduces friction between the particles as well as soil cohesion since it absorbs more water (Blainski et al., 2008). This is confirmed by the higher absolute value of "t" associated with $\mathrm{G}$ and $\mathrm{M}$ compared with $\mathrm{D}$ in model 2, indicating that $\mathrm{PR}$ is more substantially modified by variations in $G$ and $M$ than by variations in $\mathrm{D}$.

According to Peng et al. (2004), in a study on mechanisms that make soils (Acrisols) vulnerable to compaction, the parameter " $a$ " of an exponential model indicates the intrinsic resistance of dry soil and parameter " $b$ " describes the influence of soil properties such as mineralogical texture, organic matter and density on soil resistance. Since our study investigated a very clayey soil with little textural variation, the values obtained for parameter " $b$ " (in this study named $b, c$ and $d$ ), and consequently the estimated PR, are probably more influenced by soil moisture content, bulk density and organic matter content, as reported by Ribon \& Tavares Filho (2008), in a study of a very clayey eutroferric Red Oxisol under year-round citrus.

The correlation ( $r$ ) between the absolute and estimated values of PR in eutroferric Red Oxisol under annual no-till cropping (Figure 1) was 0.91 for model 1 and 0.95 for model 2 , revealing a high degree of positive correlation between the real and estimated values, as can be seen from the dispersion of points around the 1:1 straight line (Figure 1),
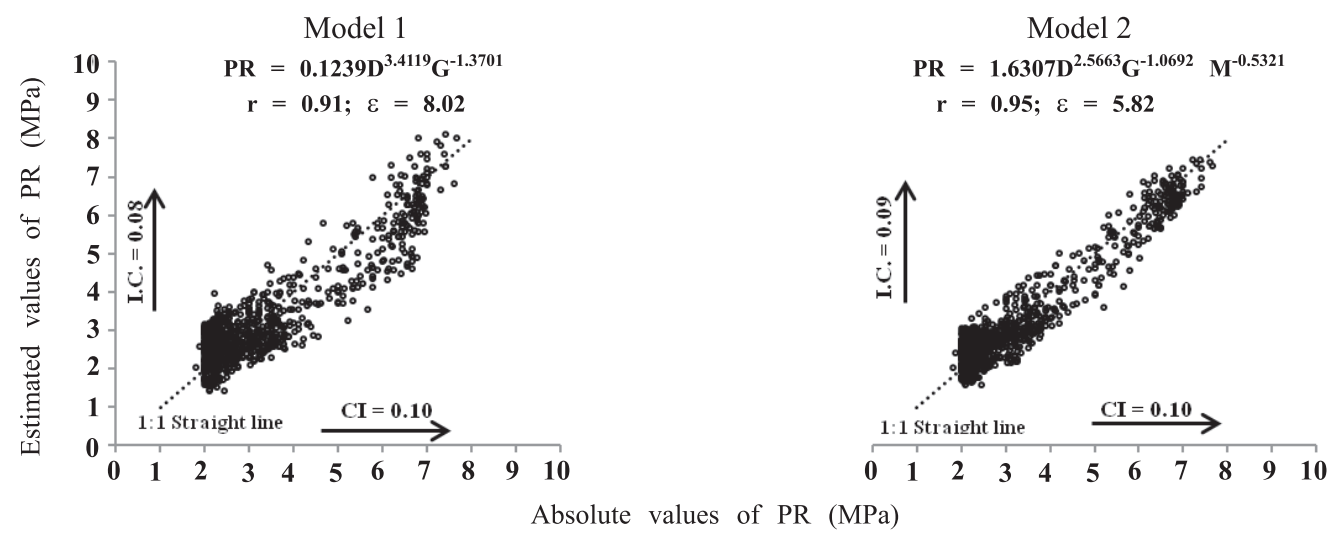

Figure 1. Absolute (real) and estimated values for soil penetration resistance (PR) in eutroferric Red Oxisol (Latossolo Vermelho eutroférrico) under annual no-till cropping. r: coefficient of correlation; $\varepsilon$ : mean absolute relative error; CI: confidence interval (95 \%). 
indicating the ideal adjustment, i.e. the closer to the straight line, the greater the accuracy of the estimate (Zhuang et al.,2001). In addition, the confidence interval (95\%) is not great, indicating the viability of the chosen model.

With regard to deviations of the model-based estimated data from the experimental data (Figure 1), the mean absolute relative errors $(\varepsilon)$ of the two models studied were adequate to describe PR, since $\varepsilon<10 \%$ (simulation - adjustments close to the experimental data) (Mohapatra \& Rao, 2005). However, for model 2, which includes $M$ in addition to $\mathrm{D}$ and $\mathrm{G}, \varepsilon$ was $2.2 \%$ lower than for model 1 and $4.18 \%$ lower than the $10 \%$ limit.

The relationship between the mean value $(\mathrm{N}=960)$ for penetration resistance determined in the field $\left(\mathrm{PR}_{\mathrm{C}}\right)$ and the value estimated $\left(\mathrm{PR}_{\mathrm{E}}\right)$ using the model: $\mathrm{PR}=1.6307 \mathrm{D}^{2.5663} \mathrm{G}^{-1.0692} \mathrm{M}^{-0.5321}$ was calculated (Table 4). Note that there is no significant difference in the $5 \%$ Tukey test between penetration resistance averages $P R_{C}$ and $P R_{E}$.

Thus, the proposed model, including $\mathrm{M}$ as well as D and $G$, allowed satisfactory fitting, based on the values of $R^{2}, r, \varepsilon$, and CI, and there was no significant difference in the $5 \%$ Tukey test between penetration resistance means $P R_{C}$ and $P R_{E}$, especially since this is a soil property that normally varies considerably.

\section{CONCLUSION}

The model including $\mathrm{M}\left(\mathrm{PR} \mathrm{R}^{\prime}=\mathrm{a} \mathrm{D}^{\mathrm{b}} \mathrm{G}^{\mathrm{c}} \mathrm{M}^{\mathrm{d}}\right)$ had a coefficient of determination of 0.91 , a mean absolute relative error of 5.82 and a coefficient of correlation of 0.95 , whereas the model that does not include $\mathrm{M}$ $\left(P^{\prime}=a D^{b} G^{c}\right)$ had a coefficient of determination of 0.82 , mean absolute relative error of 8.02 and a coefficient of correlation of 0.91 .

\section{LITERATURE CITED}

ALMEIDA, C. X.; CENTURION, J.F.; FREDDI, O.S.; JORGE, R.F. \& BARBOSA, J.C. Funções de pedotransferência para a curva de resistência do solo à penetração. R. Bras. Ci. Solo, 32:2235-2243, 2008 .

ARAÚJO, M.A.; TORMENA, C.A. \& SILVA, A.P. Propriedades físicas de um Latossolo Vermelho distrófico cultivado e sob mata nativa. R. Bras. Ci. Solo, 28:337-345, 2004.

BLAINSKI, É.; TORMENA, C.A.; FIDALSKI, J. \& GUIMARÃES, R.M.L. Quantificação da degradação física do solo por meio da curva de resistência do solo à penetração. R. Bras. Ci. Solo, 32:975-983, 2008.

BUSSCHER, W.J. Adjustment of flat-tipped penetrometer resistance data to a common moisture content. Trans. ASAE, 33:519-524, 1990.

BUSSCHER, W.J.; BAUER, P.J.; CAMP, C.R. \& SOJKA, R.E. Correction of cone index water content differences in a coastal plain soil. Soil Tillage Res., 43:205-217, 1997.

CARGNELUTTI FILHO, A. \& STORCK, L. Evaluation statistics of the experimental precision in corn cultivar trials. Pesq. Agropec. Bras., 42:17-24, 2007.

CARPENEDO, V. \& MIELNIZUK, J. Estado de agregação e qualidade de agregados de Latossolos Vermelhos, submetidos a diferentes sistemas de manejo. R. Bras. Ci. Solo, 14:99-105, 1990.

CARTER, M.R. Relations of strength properties to bulk density and macroporosity in cultivated loamy sand to loam soils. Soil Tillage Res., 15:257-268, 1990.

COLLARES, G.L.; REINERT, D.J.; REICHERT, J.M. \& KAISER, D.R. Qualidade física do solo na produtividade da cultura do feijoeiro num Argissolo. Pesq. Agropec. Bras., 41:16631674, 2006.

DEXTER, A.R.; CZYZ, E.A. \& GATE, O.P. A method for prediction of soil penetration resistance. Soil Tillage Res., 93:412-419, 2007.

Table 4. Average value $(\mathrm{N}=960)$ for penetration resistance determined in the field $\left(P R_{C}\right)$ and estimated $\left(\mathrm{PR}_{\mathrm{E}}\right)$ based on the data for $\mathrm{G}$ (gravimetric moisture content), D (bulk density) and M (organic matter content) of a eutroferric Red Oxisol under annual no-till cropping

\begin{tabular}{|c|c|c|c|c|}
\hline \multirow{2}{*}{$\mathbf{N}$} & \multicolumn{2}{|r|}{ PR (MPa) } & \multicolumn{2}{|c|}{$\mathrm{CV}$} \\
\hline & $\mathbf{P} \mathbf{R}_{\mathrm{C}}$ & $\mathrm{PR}_{\mathrm{E}}\left(\mathrm{PR}^{\prime}=1.6307 \mathrm{D}^{2.5663} \mathrm{G}^{-1.0692} \mathrm{M}^{-0.5321}\right)$ & $\mathbf{P} \mathbf{R}_{\mathrm{C}}$ & $\mathbf{P R}_{\mathrm{E}}$ \\
\hline & & & 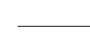 & 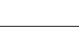 \\
\hline 960 & $3.29 \mathrm{a}^{(1)}$ & $3.30 \mathrm{a}$ & 46.7 & 43.1 \\
\hline
\end{tabular}

(1) Means followed by the same letter did not differ significantly in the $5 \%$ Tukey test; CV: coefficient of variation. 
EMPRESA BRASILEIRA DE PESQUISA AGROPECUÁRIA EMBRAPA. Sistema Nacional de Levantamento de Ciência do Solo. Manual de métodos de análise de solo. 2.ed. Rio de Janeiro, 1997. 212p.

FIDALSKI, J. \& TORMENA, C.A. Funções de pedotransferência para as curvas de retenção de água e de resistência do solo à penetração em sistemas de manejo com plantas de cobertura permanente em citros. Ci. Rural, 37:1316-1322, 2007.

IMHOFF, S.; SILVA, A.P. \& TORMENA, C.A. Aplicações da curva de resistência no controle da qualidade física de um solo sob pastagem. Pesq. Agropec. Bras., 35:1493-1500, 2000.

KHOURY JÚNIOR, J.K.; DIAS, G.P.; CORDEIRO, R.R. \& SOUZA, C.M.A. Modelagem da estabilidade de tratores agrícolas de pneus. Pesq. Agropec. Bras., 39:459-468, 2004.

LIMA, C.L.R.; REICHERT, J.M.; REINERT, D.J.; SUZUKI, L.E.A.S. \& DALBIANCO, L. Densidade crítica ao crescimento de plantas considerando água disponível e resistência à penetração de um Argissolo Vermelho distrófico arênico. Ci. Rural, 37:1166-1169, 2007.

MOHAPATRA, D. \& RAO, P.S. A thin layer drying model of parboiled wheat. J. Food Eng., 66:513-518, 2005.

OLIVEIRA, G.C.; SEVERIANO, E.C. \& MELLO, C.R. Dinâmica da resistência à penetração de um Latossolo Vermelho da Microrregião de Goiânia, GO. R. Bras. Eng. Agríc. Amb., 11:265-270, 2007.

PENG, X.H.; HORN, R.; ZHANG, B. \& ZAHO, Q.G. Mechanisms of soil vulnerability to compaction of homogenized and recompacted Ultisols. Soil Tillage Res.,76:125-137, 2004.

RIBON, A.A. \& TAVARES FILHO, J. Estimativa da resistência mecânica à penetração de um Latossolo Vermelho sob cultura perene no norte do estado do Paraná. R. Bras. Ci. Solo, 32:1817-1825, 2008.

RIBON, A.A. \& TAVARES FILHO, J. Model propositions for the estimation of the physical quality of a Yellow Red Latosol (Oxisol) under pasture. Braz. Arch. Biol. Technol., 47:25-31, 2004.
SÁ, M.A.C. \& SANTOS JUNIOR, J.D.G. Compactação do solo: Conseqüências para o crescimento vegetal. Planaltina, Embrapa Cerrados, 2005. 26p. (Documentos/Embrapa Cerrados, 136)

SAS Institute. SAS/STAT procedure guide for personal computers. 5.ed. Cary, 1991.

SILVA, A.P. \& KAY, B.D. Estimating the least limiting water range of soils from properties and management. Soil Sci. Soc. Am. J., 61:877-883, 1997.

SILVA, M.L.N.; CURI, N. \& BLANCANEAUX, P. Sistemas de manejo e qualidade estrutural de Latossolo Roxo. Pesq. Agropec. Bras., 35:2485-2492, 2000.

SILVA, V.R.; REICHERT, J.M. \& REINERT, D.J. Variabilidade espacial da resistência do solo à penetração em plantio direto. Ci. Rural, 34:399-406, 2004.

SOANE, B.D. The role of organic mater in soil compactibility: A review of some practical aspects. Soil Tillage Res., 16:179201, 1990.

STOLF, R. Teoria e teste experimental de fórmulas de transformação dos dados de penetrômetro de impacto em resistência do solo. R. Bras.Ci. Solo, 15:249-252, 1991.

STOLF, R.; FERNANDES, J. \& FURLANI NETO, V.L. Penetrômetro de impacto modelo IAA/Planalsucar-Stolf: Recomendação para seu uso. STAB, 1:18-23, 1983.

TO, J. \& KAY, B.D. Variation in penetrometer resistance with soil properties: The contribution of effective stress and implications for pedotransfer functions. Geoderma, 126:261-276, 2005.

VAZ, C.M.P. \& HOPMANS, J.W. Simultaneous measurement of soil strength and water content with a combined penetrometer-moisture probe. Soil Sci Soc. Am. J., 65:4-12, 2001.

ZHUANG, J.; JIN, Y. \& MIYAZAKI, T. Estimating water retention characteristic from soil particle-size distribution using a non-similar media concept. Soil Sci., 166:308-321, 2001. 